\title{
DESIGN AND IMPLEMENTATION OF AUTOMATED SYSTEM FOR MEASURING CAR BATTERY CAPACITY
}

\author{
M. Suchanovský, J. Molnár
}

Technical University of Košice

Letná, 9, Košice, 042 00, Slovak Republic. E-mail: marcel.suchanovsky@ student.tuke.sk, jan.molnar@tuke.sk

O. Slavko

Kremenchuk Mykhailo Ostrohradskyi National University

vul. Pershotravneva, 20, Kremenchuk, 39600, Ukraine. E-mail: slavko.elena@ gmail.com

Purpose. The purpose of this article is to design hardware for an automated system for measuring the parameters of the car battery and the subsequent approximation of its capacity and other parameters necessary to determine its condition. Originality. The paper deals with the research on the car batteries and measuring instruments to detect their parameters in order to determine a suitable software solution for automated measuring system to measure the car battery capacity. Methodology. The paper proposes one of the possibilities for development an automated system for measuring car battery capacity basing on microcontrollers system using prototyping, designing, simulation and testing techniques. Authors described the whole development process starting from computer design of the proposed device, chose the elements for hardware unit, prototyping using development boards and tools, developing program algorithms and implementing related applied software with the final results verification. Result. In this work authors proposed hardware solution of an automated system for measuring the capacity of a car battery. The whole design concept consisted of the selection of the main hardware components, which were then implemented into a complex functional unit. Following it was designed a software solution. This proposal was initiated by a program for measuring the parameters of the battery, then the calculation of the internal resistance from the measured parameters and the approximation of capacity on the basis of the detected life-span was added to this programme. A Web page was then created. Practical value. Proposed experimental sample could be practically used for automatic measurement of car battery capacity and also could be served as an experimental sample of remote measuring device. References 14 , figures 14.

Key words: battery capacity, automated system, internal battery resistance.

\section{ПРОЕКТУВАННЯ ТА РОЗРОБКА АВТОМАТИЗОВАНОЇ СИСТЕМИ ДЛЯ ВИМІРЮВАННЯ ЄМНОСТІ АВТОМОБІЛЬНОГО АКУМУЛЯТОРА}

\section{М. Сухановський, Я. Мольнар}

Технічний університет Кошице

вул. Лєтня, 9, м. Кошице, 04200, Словаччина. E-mail: marcel.suchanovsky@student.tuke.sk, jan.molnar@tuke.sk

О. Г. Славко

Кременчуцький національний університет імені Михайла Остроградського

вул. Першотравнева, 20, м. Кременчук, 39600, Україна. E-mail: slavko.elena@ gmail.com

Робота присвячена розробці апаратного забезпечення автоматизованої системи вимірювання параметрів автомобільного акумулятора 3 наступною апроксимацією ïi ємності та інших параметрів, необхідних для визначення його стану. У статті наведено результати дослідження автомобільних акумуляторів та вимірювальних приладів для визначення їх параметрів з метою винайдення доцільних програмних рішень при розробці автоматизованої вимірювальної системи для визначення ємності автомобільного акумулятора. У роботі запропонована одна 3 можливостей з розробки автоматизованої системи для вимірювання ємності автомобільного акумулятора на основі мікроконтролерної системи 3 використанням методів створення прототипів, проектування, моделювання та тестування. Автори описали увесь процес розробки, починаючи 3 комп'ютерного проектування запропонованого пристрою, вибору елементів для модулю апаратного забезпечення, створення прототипу 3 використанням спеціалізованих плат для розробки та відповідних інструментів, розробки алгоритму роботи програмного забезпечення та реалізації відповідного прикладного програмного забезпечення 3 підсумковою верифікацією отриманих результатів. У даній роботі автори запропонували апаратні рішення для автоматизованої системи вимірювання ємності автомобільного акумулятора. Концепція проектування полягає у виборі основних елементів апаратного забезпечення, що імплементуються у загальний функціональний блок. Надалі були реалізовані рішення щодо програмного забезпечення. Запропонований варіант ініціюється програмою з вимірювань параметрів акумулятора, після чого виконуються обчислення внутрішніх опорів на основі виміряних параметрів та апроксимація ємності на основі визначеного очікуваного строку роботи. Як фінальний результат, отримується веб-сторінка 3 відповідною інформацією. Запропонований експериментальний зразок може практично використовуватись для автоматичних вимірювань ємності автомобільного акумулятора, а також може слугувати як зразок віддаленого вимірювального пристрою.

Ключові слова: ємність батареї, автоматизована система, внутрішній опір акумулятора. 
PROBLEM STATEMENT. In the first part of the article we will show three methods for approximating the capacity of the car battery from measurable parameters. We choose the most feasible for hardware created from the three proposed methods. The first method relies on the internal resistance of the car battery. The internal resistance of the battery rises with its discharge and decreases when charging. This resistance is actually the sum of the resistance of cell interconnections and the resistance of the electrolyte and as the electrolyte degrades over time and does not have its original conductivity, the internal resistance of the battery continuously rises. The problem of this method is that it affects the battery charge status, as the internal resistance depends on it. The other two methods rely on the internal impedance of the battery. In the internal resistance measurement method, the capacitor capacity from the replacement electrical scheme of the battery is neglected. This capacitor plays a large role in the impedance of the battery, as its size is approximately $1.5 \mathrm{~F} / 100 \mathrm{Ah}$ of the battery capacity. From a practical point of view, this capacitor causes a slower response of the battery to the leap changes on its load. For this reason, the methods built based on the measurement of internal impedance are more accurate, but require more complex hardware security, and therefore we have chosen the method of measuring the internal resistance of the battery for our involvement. In the second part of this article we propose a software solution for calculating internal resistance, exporting measured and calculated data. Because the source codes of these operations are very lengthy and their content is listed in the first section, where the internal resistance calculations are mentioned, we will show only the flowcharts in this section, which cost the entire source codes. In the third part we will show and describe the user interface of the website.

\section{EXPERIMENTAL PART AND RESULTS} OBTAINED.

\section{Replacement battery model, parameter} determination

If we were to deal with the battery as a chemical source of Energy labelled with the battery's schematic label, this would mean that the object of our interest is the ideal battery and thus the device that can deliver an infinite amount of energy, after an infinitely long period of time and occupies infinitely small space. But the ideal battery does not exist and each battery has a limited amount of energy that can deliver for a period of time, which is reduced in addition to its age. The Parameter that characterizes this battery property is called the battery capacity and is actually the amount of electricity that the battery can supply for a specified time (by default, 5 or 20 hours) and measured in ampoules. And since we are considering the battery as an imperfect source, we cannot consider the ideal schematic brand. The replacement scheme in electrical engineering represents an engagement consisting of passive elements known as the Randwoods model of toddler E, which is shown in the Figure 1.

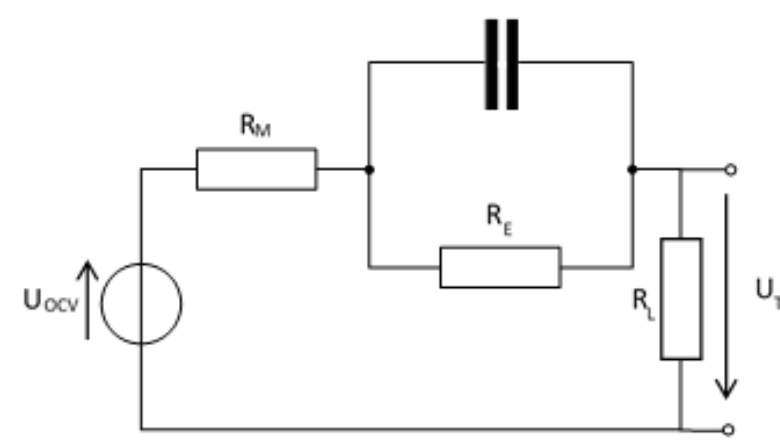

Figure 1 - Randless model

Resistor $R_{E}$ in the scheme represents limitations of the non-ideal source of electrochemical tension. The discharge of the battery causes an increase in this resistance, its recharging, conversely, the decrease, and also the value of this resistance, the temperature at which the battery is stored. The value of resistance $R_{E}$ is gradually increasing over time and therefore, measuring this resistance can help determine the end of the battery life. Resistor $R_{M}$ illustrates the resistance of metallic connections between the various articles in the battery and has a fixed value that is not altered by temperature or with age. $R_{M}$ also determines the maximum current that can provide the battery. $R_{M}$ and $R_{E}$ resistance are approximately the same and their combination is commonly referred to as the internal resistance of the battery. Resistor $R_{L}$ has a very high resistance that causes self-discharge and which is not measurable, but its inclusion in the model helps us to understand why batteries lose gradually all their charge in a long dry state. The $C$ capacitor represents a "flywheel" in the electrochemical voltage source, which causes a slower reaction of the source to change the load current. $C$ is a measurable parameter and represents a capacity of $1.5 \mathrm{~F}$ for every 100 Ah battery. $U_{O C V}(\mathrm{OCV}=$ Open Circuit voltage) is the voltage of the ideal source and $U_{T}$ is the voltage at the terminals of the battery. To Measure the internal resistance of the battery, we simply have a simple voltmeter and a resistor with a known resistance value. The battery resistance is then measured by measuring the voltage on the battery - unladen terminals, then connecting the battery pack and measuring the voltage on the battery terminals again. We will then calculate the battery resistance using the Ohm law as:

$$
R_{B A T}=\frac{U_{N}-U_{L}}{I_{B A T}},
$$

where $U_{N}$ is the voltage of the battery that is not charged, $U_{L}$ the voltage on the battery and $I_{B A T}$ is the current flowing from the battery to the circuit during measurement and we calculate it by means of a fire act as a proportion of the voltage on the battery loaded and resistance of the resistor used as a load. A simplified wiring diagram for this method of measuring the internal resistance of the battery can be seen in the Figure 2. 


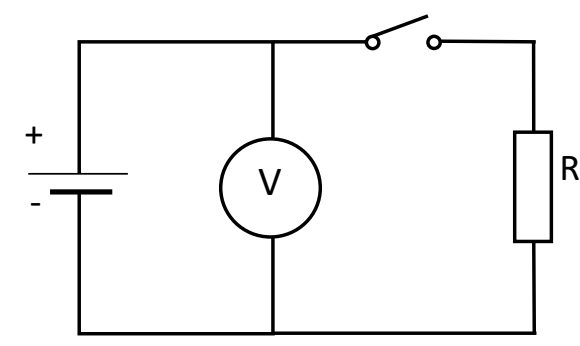

Figure 2 - Wiring diagram for measuring the internal resistance of the car battery

\section{Measurement device}

Repeat the specified product requirements before continuing and describing: all measured quantities must be measured with the highest accuracy (e.g.: The most accurate converter must be used as accurately as possible and must be properly calibrated), measured and calculated parameters must be transmitted to the user via the Wi-Fi interface, the user must be of the measured and calculated parameters to clear what life has its battery and Must be able to predict the end of the battery life (the battery will not be able to start the car). In this article, we design a device based on the required parameters, which will be based on the theoretical design in the previous article, the block diagram of which we can see in Figure 3.

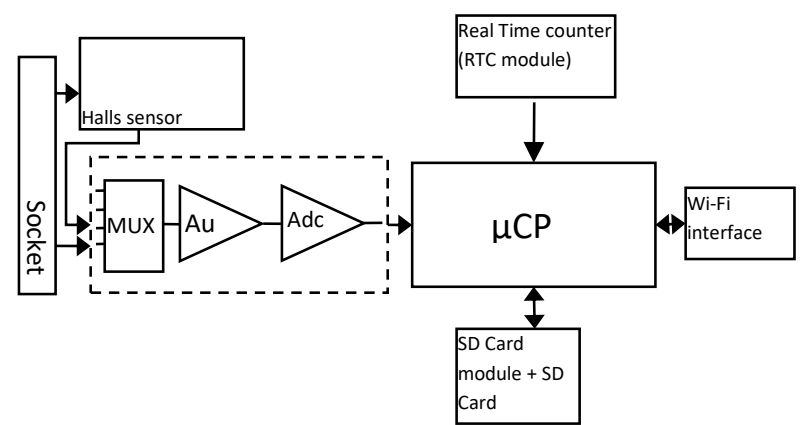

Figure 3 - Block wiring diagram for the automated battery life measurement device

\section{Microcontroller and Wi-Fi interface}

The microcontroller is the most important part and the head of the entire measuring device. When selecting a microcontroller, it is important to take a number of parameters: Optimum Performance - The higher the performance, the more calculations per second The microcontroller can handle, thereby increasing the chance that the microcontroller will measure and calculate an unforeseen change in voltage, current or any of the calculated parameters and thus it may indirectly affect the accuracy of the device itself. The Power ("speed") of the microcontroller itself is not the only part of determining the overall speed or performance of the device, in the case of auxiliary modules and peripherals, the overall speed of the device may also slow down these devices, or the communication interface they use, and in addition to the increasing performance of the microcontroller, the price is also increasing. It is therefore necessary to choose the power of the microcontroller so that it is not the slowest part of the system, but does not have excessive power, which only unnecessarily increases the price of the device, when the overall performance of the device system will always be given its slowest part. Other important parameters for selecting the right microcontroller for our project are: The size of the internal memory (especially for the code, since it is difficult, if at all can be extended), built-in peripherals (availability of all necessary communication interfaces, other peripherals, which we would need to complement the modules), the number of usable I/O ports. Because of the need for our project to have a $\mathrm{Wi}-\mathrm{Fi}$ interface, it is very convenient to choose a microcontroller, which also has this interface between the built-in peripherals. We will demonstrate several options for selecting the head of our entire device and thus, the development board with a microcontroller fitted.

\section{A. LOW COST - ESP8266 + IO expander}

The cheapest option with theoretically fulfilled requirements is the use of the NodeMCU Development Board with the established microcontroller ESP8266. Well the price is probably the only advantage of this option and the disadvantages will be a little more. In the first place, the entire program will run on a single processor, and thus the processor will also need to cater to the operation of the website and the measurement and calculation of parameters. If, for example, a user has just used a web interface, there might be a situation where the device would be overwhelmed by the requirements of the user who wants to control the starting current, and the processor would take the display on the Web page at the time of the highest peak, and until it returns to the reading of new values from the converter, the next value would be measured. In this case, the whole measurement would be inaccurate and would have lost significance. Another problem with using this development Board is the number of $\mathrm{I} / \mathrm{O}$ pins. ESP8266 has up to 17 IO pins, but many of them are used by the NodeMCU development board itself and, in the case of their use, the recording of new codes could be prevented or fatal damage to the board could occur. For example, 6 pins are used for FLASH memory, whereas the microcontroller has not built-in. Although it sounds like an advantage, on these 6 pins it is possible to connect memory with a maximum of $32 \mathrm{MB}$ of storage, which is for our data retention needs too few. In addition, ESP8266 contains various other pins, which, while in active mode, can be used while recording a program on them cannot be a logical value of 0 or 1 . One way to solve this problem is to use an IO expander, a device that extends the microcontroller to several I/O pins. But there is a stone accident again, as the device must communicate with the microcontroller (usually I2C or SPI interface) and thus again some precious computing time of the processor we sacrifice to communicate with another device. To resolve both the basic errors of the microcontroller ESP8266 could be connected by another microcontroller, e.g.: ATMEL MEGA328P mounted on the Arduino UNO Development Board. 


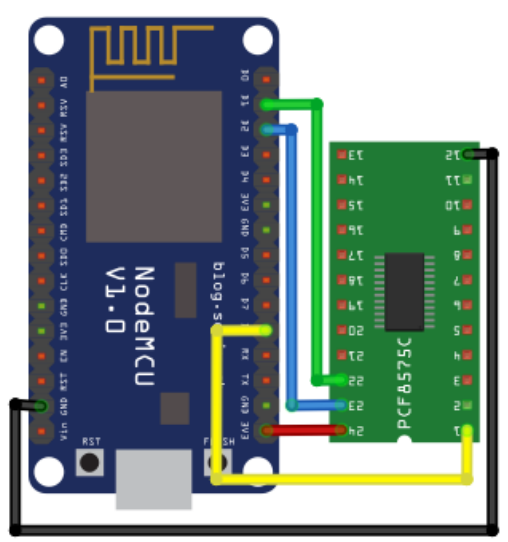

Figure 4 - Connection diagram of NodeMCU development board and IO expander created in FRITZING program

\section{B. HIGH PERFORMANCE - Arduino UNO + ESP8266}

The exact opposite of the first option and thus the use of the NodeMCU in has only been its use only as a Wi-Fi module to another microcontroller. In this case, the price would also be increased twice, at a price that we would also receive double computing power. And thus, it would be possible to address a particular program for displaying information using the Wi-Fi interface and especially the program for their measurement and calculation. In this case, it would be the lowest probability of skipping an important leap change of the measured parameter, and thus we can say that the device would be the most accurate. Although in this case there must be communication between the two microcontrollers, the data in progress can be processed and stored by a microcontroller serving the website (ESP8266) and a microcontroller serving the measurement and calculation of parameters (ATMEL MEGA328P) only sends the data over the serial line without undue delay.

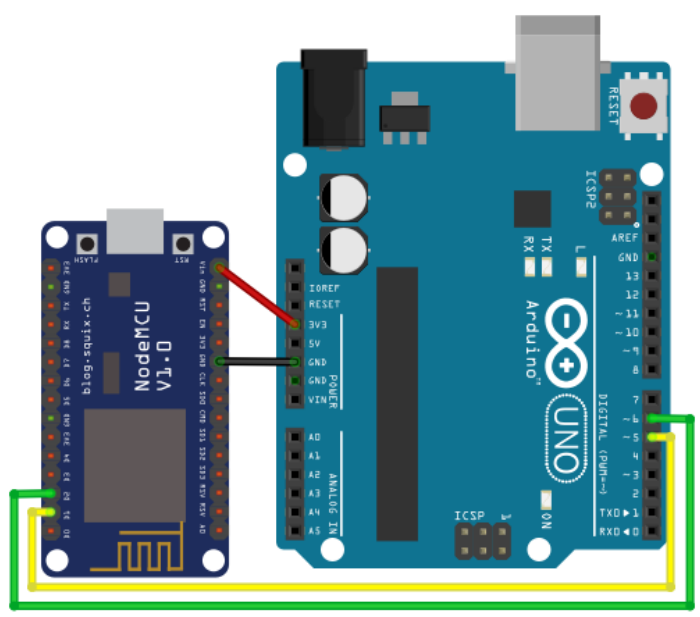

Figure 5 - Wiring diagram of NodeMCU and Arduino UNO development boards created in FRITZING program

C. GOLDEN MEAN-ESP32

The biggest problem with using ESP8266 as a programmable microcontroller is the number of its $\mathrm{I} / \mathrm{O}$ pins. This is because the manufacturer Espressif originally did not create the microcontroller ESP8266 for programming, but only to use as a Wi-Fi module. However, for practical reasons, programmers have found a way to program this microcontroller. Due to its popularity, the manufacturer has removed the largest defect in the second model referred to as ESP32. The number of I/O pins increased from 11 theoretically usable to 18 fully usable GPIO pins (and from a total of 17 to 48 GPIO pins, while the remaining is used for microcontroller operation) and an additional 8 usable with restrictions. In addition, one more computing core has been added to the microcontroller, and thus the processor is dual-core, so one core can handle measurement and parameter calculation and the other core can deal with displaying data on the website and operate the website itself. The processes would thus be independent of one another without the need for two microcontrollers. The only disadvantage compared to ESP8266 is double the price, but with respect to the whole device, it is convenient and usable and therefore we chose this option as the most effective and we construct the device with the help of development boards with fitted microcontroller ESP32, which can be seen in Figure 6.

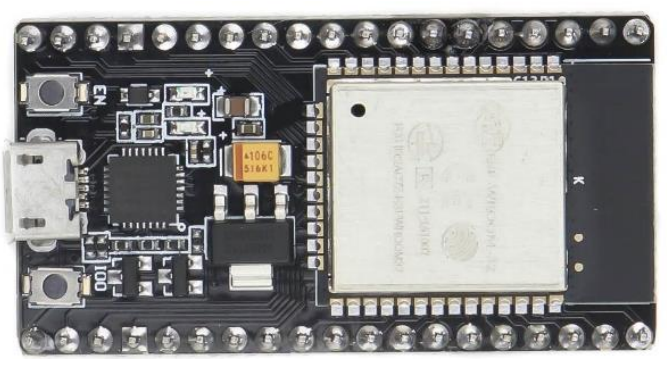

Figure 6 - Development board ESP32

\section{ADC Converter}

The second most important part of the measuring device is the analog to digital converter (ADC). Many microcontrollers have an integrated ADC as a periphery. Typically, this converter has a resolution of 10-12 bits, and this also applies to the above three microcontrollers: MEGA328P and ESP8266 have a built-in 10-bit and ESP32 12-bit ADC. Since we need to measure a relatively wide range of currents $(0-300 \mathrm{~A})$ with as much precision as possible, it is certainly not sufficient to give us the 4096 values provided by 12 bit ADC built in ESP32, where a resolution of $1 \mathrm{~A}$ would make up about 13 converter values, or in other words we would measure the current with an accuracy of $73 \mathrm{~mA}$ which is very inaccurate. In case if we would like to find microcontrollers with built-in precision $\mathrm{A} / \mathrm{D}$ converters, we would like to have a microcontroller designed for measuring instruments and are not likely to be programmable. Therefore, we must reach the external A/D converter, which will connect to the microcontroller as the next periphery either through a communication interface, or simply attach the measured data to the serial line. The advantage of converters that 
communicate with communication interfaces is that only as many drivers as they need to connect with the micro-controller, and with this communication, the entire converter will also send data from the converter to the microcontroller. The downside is that the communication interface itself brings a delay to this converter, as it must convert the data into a suitable form for sending after a given serial bus. The Disadvantage of converters, which do not communicate with any standardised protocol, is that more drivers are needed to run them, but the advantage is that the data is available immediately after the measurement without being transferred to a shape suitable for transmission after the bus. The method of communication is not what is distributed by itself ADC's. These are divided by building on: comparative, compensatory, integrative, and double integration and Delta Sigma converters. The largest linearity at our required high resolution provide transducers with delta-sigma modulation. This is achieved even at resolutions of up to 24 bits, so we have been looking for modules with Delta-Sigma converters for our use. The Disadvantage of these converters is that they can handle a maximum of a few hundred to thousands of transfers per second, but this should be enough for our purposes. The ADS1232 converter is made by us with a built-in crystal $(4,9 \mathrm{MHz})$ maximum of 80 transmissions per second. In order not to connect a multiplexer and an operating amplifier to the converter, the circuit of the wanted converters has narrowed to those two devices integrated. The result of our search is the ADS1232 Converter, which is only produced in TSSOP (Thin Shrink Small Outline Package) sizes, so we bought it on the circuit board, due to the need for wiring in the test circuits. This board with mounted converter can be seen in Figure 7.

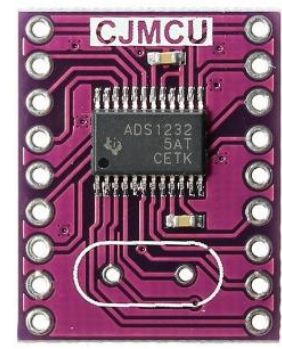

Figure 7 - Analog to digital converter ADS1232

\section{E. Halls sensor}

In order to measure the current flowing from the car battery, either during the start-up or even running of the car, a suitable current measurement device must be connected. If we would like to measure the current with the bypass, the installation of the measuring device into the car would be more complex and we would have to use a side with such resistance to not restrict the operation of the power equipment such as the starter, and also to avoid damage to the overcurrent. On the other hand, if there is a hall sensor used to measure the current, the sensor will not damage or affect the operation of other devices when using the sensor on the lower currents. In particular, because of the ease of installation of the device to the car by the user, we used our proposed equipment to measure the stream of the hall sensor. The latter may be less accurate than the bypass because of interference, but this measurement accuracy is enough for our needs. To ensure minimal accidental motion of the sensor, we chose sensors with toroidal split core. The base criterion was to make the hall sensor was able to accurately measure the current even larger than $150 \mathrm{~A}$, which was our assumption of the starting current. Hall sensor HST21 can handle the current up to $300 \mathrm{~A}$ (and Peak current $900 \mathrm{~A}$ ) with linearity permits highly $99.99 \%$. The drawing of this Hall sensor is shown in Figure 8.

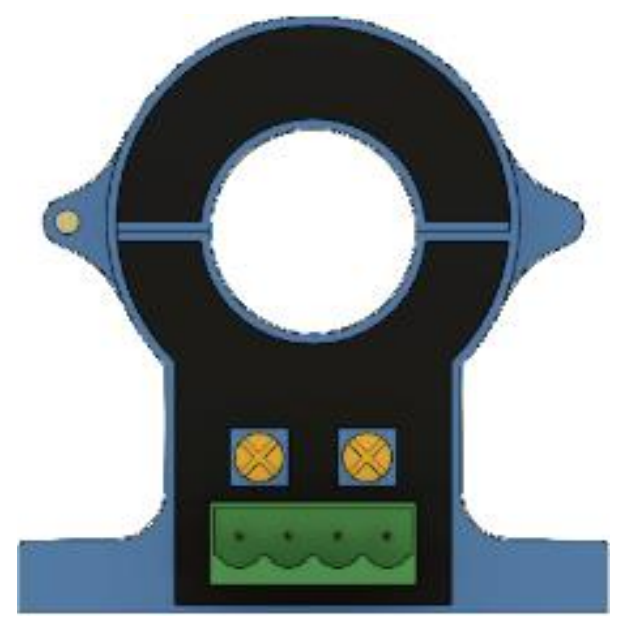

Figure 8 - Drawing of hall sensor HST21 from FUSION 360 program

\section{Final connection}

The final connection was made using the individual components we have already mentioned. In the final connection there are two unrecognized elements, RTC module and SD card module.

We did not mention the choice of these two devices, because these two components do not carry any key role in our measuring equipment and therefore their selection was made only based on price. The RTC module is based on the DS1307 real time counter. The SD card module contains only an SD card slot and a level shifter, which only serves to change the voltage values between the SD card and the microcontroller. The connection can be seen in Figure 9. Since the wiring was created by Fritzing, it was relatively easy to generate a circuit board design from it, but it had to be refined and modified. The PCB design is no longer fitted with a Hall sensor, since it will not be permanently connected to the board but will only be connected by cables. The sensor is therefore replaced by four connectors, although they were also shown in the graphic connection, but there were only by principle. Created, modified design of one-sided printed circuit board is shown in Figure 8. The connection consists of a development board with microcontroller ESP32, AD converter ADS1232, hall sensor HST21, RTC module with DS1307 chip, module for SD card, voltage divider made up of two resistors and voltage regulator acting as the source in the circuit is shown in Figure 10. 


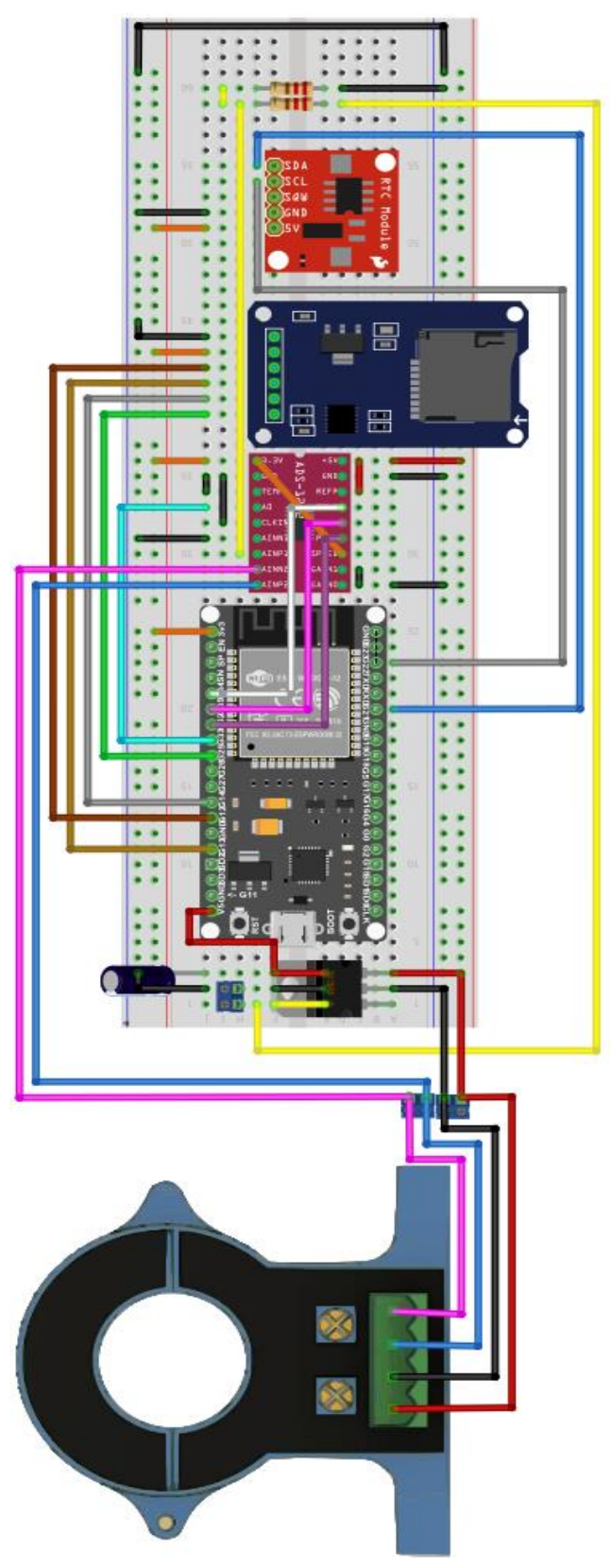

Figure 9 - Connection of the device for measuring the condition of the car battery created in the FRITZING program

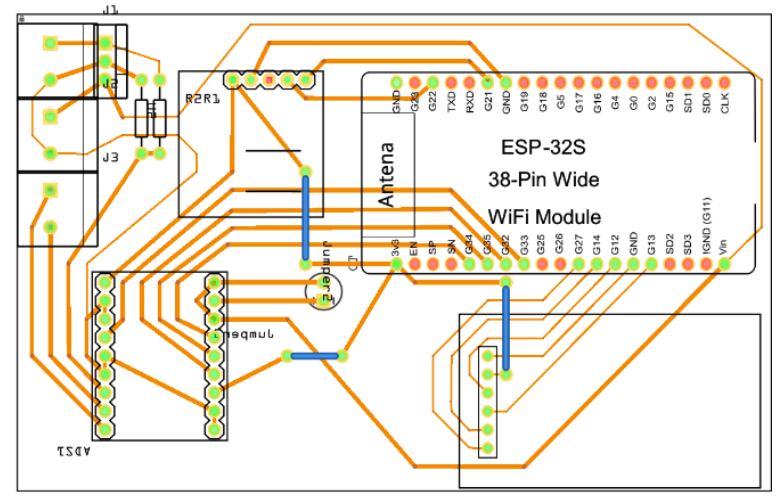

Figure 10 - Drawing of hall sensor HST21 from FUSION 360 program
Automated metering system

In the context of the software proposal in this article, three basic processes were needed: measuring and calculating parameters, processing and rendering of measured and calculated parameters, and displaying parameters on a Web page. The first two processes are handled by the main microcontroller of the device and thus ESP32, for which we have used the advantage of a dual-core processor to divide these processes into custom threads. Although the third process is processed by the main microcontroller of the device, but the main part of the process and therefore the user's information is in charge of the terminal equipment connected to the measuring system (smartphone, computer,...), namely its web browser.

The source code of the first process is created in the Arduino IDE interface and it is a number of simple subprocesses whose main task is to calculate the battery capacity. Voltage and current measurement are not complex functions, it is only about reading the values from the ADC and their subsequent recalculation to the exact value using the calibration constants. For this reason, we will not draw the flowchart or source code of these functions here, and we will further consider them as predefined features for further use in other more complex functions. The first of this function is to measure the internal resistance of the car battery and its source code is controlled by the flowchart drawn in the Figure 11.

When you run the program to measure the resistance of the car battery, the device will determine whether the voltage is lower than $13 \mathrm{~V}$ In order to determine whether the car is no longer started and therefore the battery is rechargeable. If the condition is met, the device measures the current running of the battery. When the vehicle is suspended, it is assumed that this current stream will move well below $1 \mathrm{~A}$ but after turning the key to position 1 , the comfort electronics will begin to load and the engine is ready to start by heating up, pumping the fuel with the pump, etc. And, therefore, the device determines whether the current does not exceed $5 \mathrm{~A}$ (so that the device does not expect to start at any minor leap change in the vehicle's quiet condition). When the condition is met, the device measures the voltage and current until the battery is charging the alternator of the vehicle, i.e. the voltage on its terminals does not exceed $13 \mathrm{~V}$. Until this condition is met, the device is looking for the highest current value of the battery and the lowest voltage on the terminals of the battery (this condition occurs simultaneously, as the voltage on its terminals decreases with the increasing current from the battery). When this condition is met, the device calculates the internal resistance of the car battery by using the last voltage of "unladen" batteries (before start), the lowest voltage values during start-up and the highest value of the current. The second main diagram is the calculation of the car's capacity. This flowchart is simpler because no further measurement is used to measure capacity, only approximates from internal resistance based on the lifetime of the life. The flowchart for capacity calculation can be seen in the Figure 12 . 


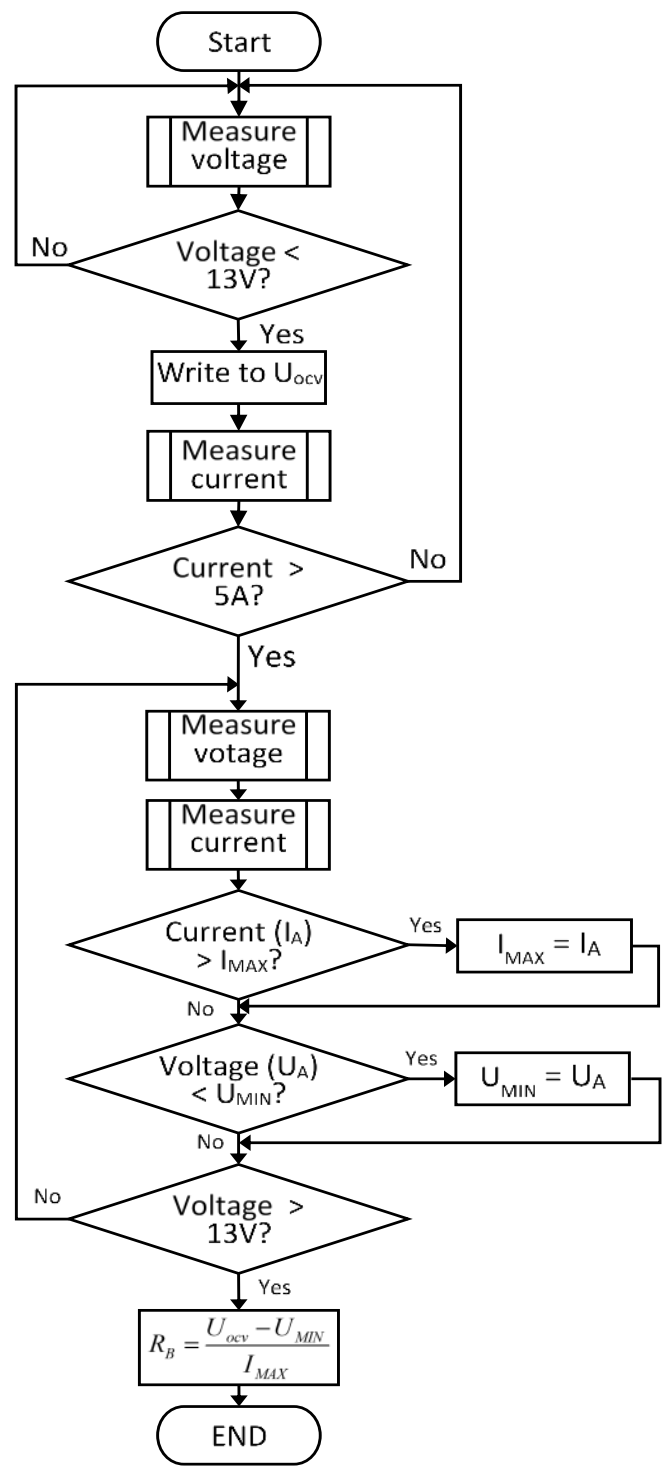

Figure 11 - Flowchart for calculating the internal resistance of the battery

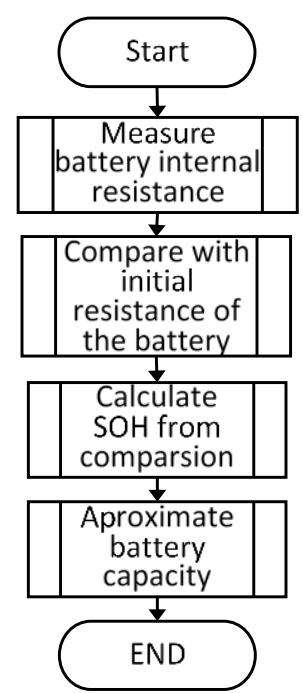

Figure 12 - Flowchart for approximating battery capacity
Implementation of the software design

Calculation and display of parameters is in charge of the main microcontroller ESP32. For the provision of data to the user was a microcontroller created a Web page, written IN HTML and ENRICHED with several elements of CSS styles, which helped to intuitivity the design of the site. The dynamic display of the time, and all the timephased elements of the page, were made using Javascript and the jQuery library. The design of this page was then saved to the SD card and the microcontroller has added a program to display pages from this memory, where in addition to the site itself is also saved the jQuery library, and text files with battery data. The graphs shown on the page show the time variability of measured and calculated parameters are rendered by microcontrollers as SVG images. These pictures, as well as the last measured data, are not stored on the card, but are stored on separate servers, the content of which is always only a text document with the last value or a rendered picture. The website can be seen in the Figure 13.

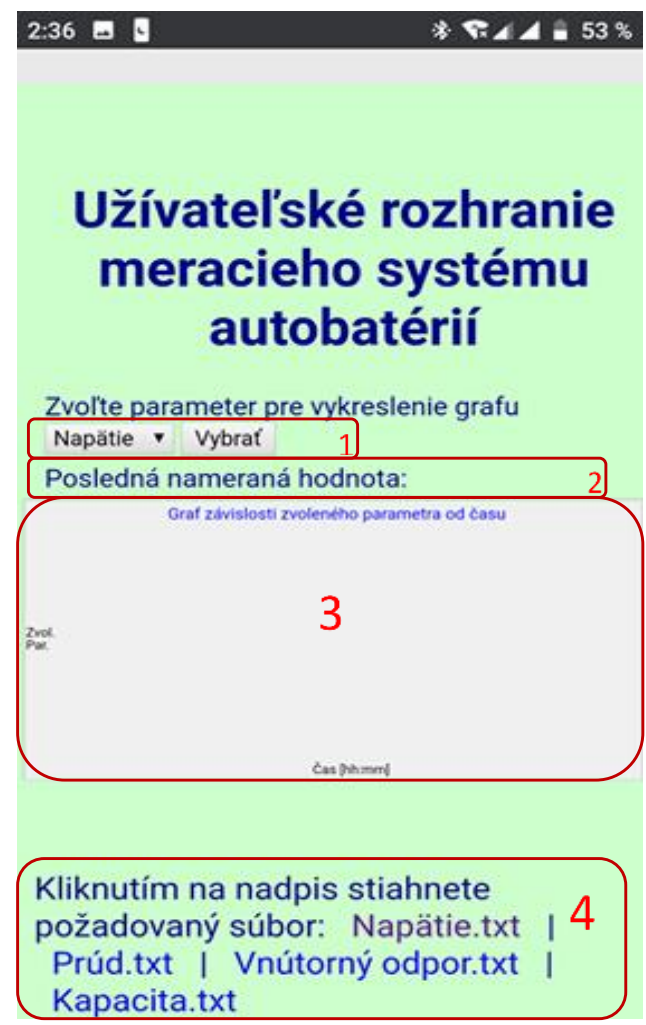

Figure 13 - Automated system user interface

The image is marked on the Not Loaded page 4 fields. Until you select one of the variables in field 1, the page will remain in this view, where the current time is only dynamic. Field 4 remains static even after selecting a parameter, in this field, you can click on a specific inscription to download a file with the values from which the chart was rendered. This file contains the last 1500 values of the measured quantity and a specific time stamp containing the full date and time format. All 4 data files are on the SD card and are replanted sequentially after 10 values. To do this, click 
on the box with the inscription of the selected parameter (current voltage), the device will list the parameters that are for selection-voltage, current, resistance, capacityand after selecting one of them, press the Select button. After selecting a specific parameter, the last measured value of the selected parameter will appear immediately in box 2 and the last 20 figures will appear in box 3. In Figure 14 is a Web page with retrieved values after selecting the voltage parameter.

In addition, when you select a specific last measured value that is retrieved from a special page that contains one of these specific data, the other marked changes are also worth noticably. In particular, the chart description changes the name of the measured parameter and the description of the $y$-axis in the format: The electrical mark of the measured quantity [display unit of quantity]. The values on the $\mathrm{x}$ - and $\mathrm{y}$-axis are part of the chart and are rendered together with it in the form of an SVG image.

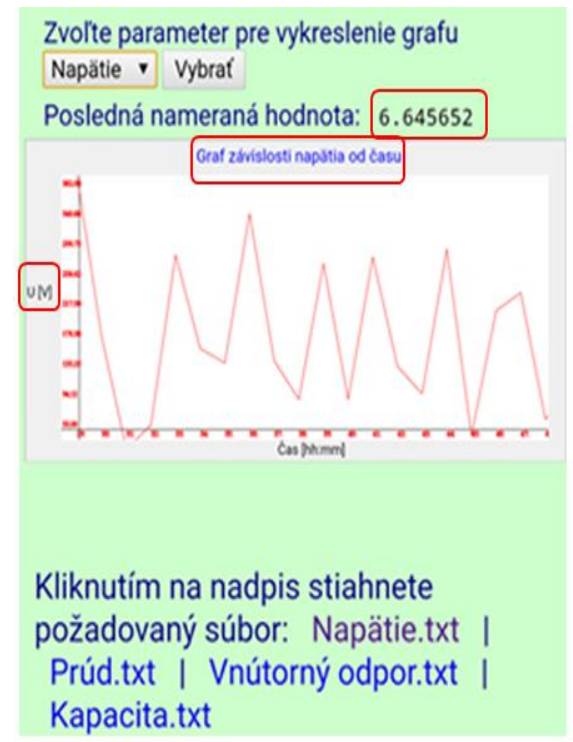

Figure 14 - Web pages after selecting a specific parameter

CONCLUSION. In this article, we dealt with the hardware solution of an automated system for measuring the capacity of a car battery. The whole design concept consisted of the selection of the main hardware components, which were then implemented into a complex functional unit. In the next section we designed a software solution. This proposal was initiated by a program for measuring the parameters of the battery, then the calculation of the internal resistance from the measured parameters and the approximation of capacity on the basis of the detected life-span was added to this programme. A Web page was then created.

\section{REFERENCES}

1. ESP32 Overview [CIT. 6.2.2020] Retrieved from https://www.espressif.com/en/products/hardware/ esp32/overview

2. Vince, T., \& Kováčová, I. (2007). Distance control of mechatronic systems via Internet. Acta Electrotechnica et Informatica , 7, 3, 63-68. ISSN 13358243

3. Arduino UNO Overview [online] [CIT. 6.2.2020]. Retrieved from https://www.arduino.cc/en/Guide/ArduinoUno>

4. Kováčová, I., \& Kováč, D. (2006). Electromagnetic coupling - EMC of electrical systems. International Review of Electrical Engineering (IREE), 1, 3, 323-329. ISSN 1827-6600.

5. HST21 - 300A Datasheet [CIT. 6.2.2020]. Retrieved from https://www.alldatasheet.com/datasheetpdf/pdf/1154682/YHDC/HST21-300A.html>

6. Bereš, M. et al. (2018). Current Ripple Comparison of Multi and Single Phase Buck-Boost Converters. MEES 2017 : International Conference on Modern Electrical and Energy Systems, New York (USA) : Institute of Electrical and Electronics Engineers, 260-263. ISBN 978-1-5386-1750-2.

7. How to measure the capacity [CIT. 7. 4. 2019] Retrieved from https://batteryuniversity.com/learn/ article/bu_907a_battery_rapid_test_methods

8. Jacko, P. et al. (2018). The parallel data processing by nucleo board with STM32 microcontrollers, MEES 2017, New York : IEEE, 264-267. ISBN 978-153861750-2.

9. Measuring the flow of the hall probe [CIT. 10. 4. 2019] Retrieved from https://www.sensorsmag.com/ components/measuring-current-imc-hall-effecttechnology>

10. Kováčová, I. et al. (2004). Neural network linearization of pressure force sensor transfer characteristic, INES 2004, Cluj-Napoca : U.T.PRES, 79-82. ISBN 9736621200.

11. Monitor battery capacity and resistance as part of aging [CIT. 18. 5. 2019] Retrieved from https://batteryuniversity.com/index.php/learn/article/ho w_age_affects_capacity_and_resistance>

12. Vince, T. et al. (2018). Android application supporting developed web applications testing, MEES 2017, New York : IEEE, 392-395. ISBN 978-1-53861750-2.

13. Voltage of car batteries in and without load [CIT. 20. 5. 2019] Retrieved from https://hielectric.com/sk/voltage-of-the-car-battery-under-loadand-without-it-how-to-measure-the-voltage-of-the-carbattery/

14. Tomčíková, I. et al. (2018). Interaction between magnetic and stress field in ferromagnetic core of magnetoelastic pressure force sensor, MEES 2017 : International Conference on Modern Electrical and Energy Systems, New York (USA) : Institute of Electrical and Electronics Engineers, 124-127, ISBN 978-1-5386-1750-2 


\section{ПРОЕКТИРОВАНИЕ И РАЗРАБОТКА АВТОМАТИЗИРОВАННОЙ СИСТЕМЫ ИЗМЕРЕНИЙ ЁМКОСТИ АВТОМОБИЛЬНОГО АККУМУЛЯТОРА}

М. Сухановский, Я. Мольнар

Технический университет Кошице

Летна, 9, 042 00, Кошице, Словакия. E-mail: marcel.suchanovsky@student.tuke.sk, jan.molnar@tuke.sk

\section{Е. Славко}

Кременчугский национальный университет имени Михаила Остроградского

ул. Первомайская, 20, г. Кременчуг, 39600, Украина. E-mail: slavko.elena@gmail.com

Работа посвящена разработке аппаратного обеспечения автоматизированной системы измерения параметров автомобильного аккумулятора 3 последующей аппроксимацией её ёмкости и других параметров, необходимых для определения его состояния. В статье приведены результаты исследования автомобильных аккумуляторов и измерительных приборов для нахождения их параметров с целью определения целесообразных программных решений при разработке автоматизированной измерительной системы для установления ёмкости автомобильного аккумулятора. В работе предложена одна из возможностей разработки автоматизированной системы для измерения ёмкости автомобильного аккумулятора на основе микроконтроллерной системы с использованием методов создания прототипов, проектирования, моделирования и тестирования. Авторы описали весь процесс разработки, начиная с компьютерного проектирования предложенного устройства, выбора элементов для модуля аппаратного обеспечения, создания прототипа с использованием специализированных плат разработчика и соответствующих инструментов, разработки алгоритма работы программного обеспечения и реализации соответствующего прикладного программного обеспечения с заключительной верификацией полученных результатов. В данной работе авторы предложили аппаратные решения для автоматической системы измерения ёмкости автомобильного аккумулятора. Концепция проектирования состоит в выборе основных элементов аппаратного обеспечения, которые имплементируются в общий функциональный блок. В дальнейшем были реализованы решения по программному обеспечению. Предложенный вариант инициируется программой измерения параметров аккумулятора, после чего выполняются вычисления внутренних сопротивлений на основе измеренных параметров, и аппроксимация ёмкости на основе определённого ожидаемого срока работы. В качестве финального результата получается вебстраница с соответствующей информацией. Предложенный экспериментальный образец может практически использоваться для автоматических измерений ёмкости автомобильного аккумулятора, а также может служить в качестве образца удалённого измерительного прибора.

Ключевые слова: ёмкость батареи, автоматизированная система, внутреннее сопротивление аккумулятора.

Стаття надійшла 15.11.2020. 